\title{
ASSESSMENT OF WATER QUALITY IN COAL MINES: A QUANTITATIVE APPROACH
}

\author{
H. L. Yadav and A. Jamal \\ Indian Institute of Technology, (Banaras Hindu University) Varanasi, India. \\ *E-mail: hiralalyd@gmail.com
}

\begin{abstract}
The water quality in mines is a major issue of concern globally. Coal mines in India have relating good quality of water with only a few exceptions. There are more than 36 parameters to explain the quality of water in a particular water body. There may be one index value which will decide the quality of water in quantitative terms. In this paper, an attempt has been made to give an index of water collected from coal mines of India with the help of methods of water quality index available. The water samples collected from mines were analyzed for 13 physicochemical parameters likes, $\mathrm{pH}$, turbidity, hardness, magnesium, chloride, calcium, nitrate, sulphate, total dissolved solids, electrical conductivity, iron, DO and BOD. The water quality index of these mine water samples varies from 26.79 to 19719.84.The higher value of WQI has been found very inferior quality due to the presence of iron, nitrate, hardness and sulphate, in the sump water sample. The obtained results from laboratory analysis can be used to propose suitable treatment process for using the water for different purposes.

Keywords: Water Quality Index (WQI), main sump water, seepage water, Physico-chemical parameters, coal mines.
\end{abstract}

(C) RASĀYAN. All rights reserved

\section{INTRODUCTION}

Water is an important constituent for the rural and urban environment and essential for all living organism, particularly for human life; however, its quantity, quality, and sufficient availability oscillate with space, time and ecological condition. Due to vast urbanization and industrialization, the contamination level in the water body, day by day, increasing from many sources and its impact can take a variety of forms. ${ }^{1-2}$ The availability of water on earth for human utilization is very less (1\%).This available water resource is presently degraded by many anthropogenic and geogenic activities. ${ }^{3-9}$ The contamination of water resources in the mining areas are due to the mine water, dumps of overburden, tailing ponds, surface impoundments, effluents from industries and acid rock drainage. ${ }^{8-10}$ Which is responsible for degradation of water quality status of surface and groundwater regime. ${ }^{11}$ Which create an unhealthy condition for all living form. ${ }^{12}$ Approximately $80 \%$ major and minor diseases were found in the human body due to severe contamination of water resources. ${ }^{13-14}$ Once the water resource is polluted, restoration of its original quality will be extremely tough and too expensive. At present all mining industries are having a particular management plan to protect the natural water quality and the environment surrounding mines area. The mine water characteristics depends on many factors like, the intensity of rainfall, reactive properties of rocks through which rain water flows, porosity, permeability, interaction duration between water and rocks, types of mining methods and involvement of major and minor machinery during a different mining operation, the composition of host rocks and some local environmental factors also influence the water quality, which produced suspended solids, and fine dust, the elemental composition of coal and minerals, which are severe sources of water quality degradation. However preservation of water quality, protection of physicochemical characteristic of downstream and protection of recreational water are additional properties in and around the mining industries. The main aim of the study is to use mine water for different purposes based on the obtained values of WQI to systematize the efficient and suitable water management plan.

Rasayan J. Chem., 11(1), 46-52(2018)

http://dx.doi.org/10.7324/RJC.2018.1111961 
WQI has been used to examine the water quality ${ }^{15}$ in many Asian, African and European countries ${ }^{16}$ including, Argentina, Brazil, Chile, China, India, Iraq, Mexico, Malaysia, Nepal, Spain, and Turkey ${ }^{17}$ to maintain the quality of natural water resources.

\section{Materials and methods}

\section{EXPERIMENTAL}

The study area is partly situated in district Sonebhadra and Singrauli of Uttar Pradesh and Madhya Pradesh respectively, out of total area $2200 \mathrm{sq} \mathrm{km}$, approximately $80 \mathrm{sq} \mathrm{km}$ in the Sonebhadra district, while the remaining major parts of the Gondwana basin are included in the Sidhi and Shahdol districts of Madhya Pradesh. On the state boundary of MP and UP, Which bounded within the geo-coordinates $23^{\circ} 47^{\prime}$ and $24^{\circ} 12^{\prime}$ latitudes and $81^{\circ} 48^{\prime}$ and $82^{\circ} 52^{\prime}$ longitudes. The entire Coalfield area is estranged into two parts of the Kachni River in-Moher sub-basin and Singrauli main basin, the division being along $82^{\circ}$ longitudes. Its major and minor parts situated in the district Sidhi and Sonebhadra of Madhya Pradesh and Uttar Pradesh respectively.

\section{Objectives of the study}

- The present study assesses the characteristics of mine water in major coal fields by calculating the (WQI) in different sampling location.

- To find out the water quality of sump water inside the coal mines.

- To compare the obtained water quality results with standards prescribed by (WHO) for drinking water.

The water samples for the physicochemical study was collected from five mine sump and seepage from Bench. The physical parameters, like temperature $\left({ }^{\circ} \mathrm{C}\right), \mathrm{pH}$, electrical conductivity (EC) (in $\mu \mathrm{S} / \mathrm{cm}$ ), Dissolved oxygen (DO) (in $\mathrm{mg} / \mathrm{L}$ ) and total dissolved solids (TDS) (in $\mathrm{mg} / \mathrm{L}$ ) were determined on the sampling location with the help of Hanna Multiparameter $\mathrm{pH}$ meter and other parameters like, calcium, chloride, magnesium, nitrate, sulphate, turbidity, total hardness, and bio-chemical oxygen demand in $(\mathrm{mg} / \mathrm{L})$ were made in the departmental laboratories as per the usual procedures prescribed in APHA. ${ }^{18-19}$

\section{Calculation of Water Quality Index (WQI)}

The idea of water quality status classification started 1848 in Germany based on the degree of water purity. ${ }^{20-21}$ The WQI is a mathematical technique for ranking the water quality, which reflects the compound effect of the different water quality parameters ${ }^{22-24}$ on the whole quality of water. It reduced the numerous of water quality parameters in a simple and useful arithmetical value. ${ }^{25}$ This is a very useful tool for people, policymakers and stakeholders ${ }^{26}$ for communicating the overall water quality ${ }^{27-28}$ in a single numerical value ${ }^{29}$ in place of various water quality parameters in the water sector. In this analysis standards recommended values are consider inversely proportional to the corresponding parameters for the calculation of corresponding weights parameters ${ }^{30}$ in this study water sample collected from five mine sump and one seepage water in 5 liters clean plastic gallon and analyzed for thirteen parameters namely $\mathrm{pH}$, total dissolved solids, electrical conductivity (in $\mu \mathrm{S} / \mathrm{cm}), \mathrm{DO}$, calcium magnesium, chloride, nitrate, sulphate, total hardness, biochemical oxygen demand ( in $\mathrm{mg} / \mathrm{L}$ ) and turbidity in (NTU), and show in Table-2. The analysis results of water sample of the WQI calculated by using the standards guideline suggested by the BIS (BIS: 10500), (ICMR) and (WHO) have been used for computation of water quality index for drinking water and shown in Table-3 and Fig.-2.

The Water Quality Index for the water body is evaluated by using the technique of Weighted Arithmetic Index. ${ }^{30-31}$ It's important mathematical relationship given as below:

$\mathrm{WQI}=\Sigma \mathrm{Q}_{\mathrm{i}} \mathrm{W}_{\mathrm{i}} / \Sigma \mathrm{W}_{\mathrm{i}}$

Where $\mathrm{Q}_{\mathrm{i}}$ is the Quality rating scale, Wi is the unit weight and suffix i shows the number of parameters.

$\mathrm{W}_{\mathrm{i}}=\mathrm{k} / \mathrm{S}_{\mathrm{i}}$

Where $\mathrm{k}=1 / \Sigma 1 / \mathrm{S}_{\mathrm{i}}$ 
Where, $\mathrm{k}$ is the constant of proportionality, and $\mathrm{Si}$ shows the standard permissible valve for $\mathrm{i}^{\text {th }}$ parameter The value of (Qi) for all water parameter is calculated by the subsequent equation:

$\mathrm{Q}_{\mathrm{i}}=100\left[\left(\mathrm{~V}_{\mathrm{i}}-\mathrm{V}_{\mathrm{o}}\right) /\left(\mathrm{V}_{\mathrm{s}^{-}}-\mathrm{V}_{\mathrm{o}}\right)\right]$

Where, $\mathrm{V}_{\mathrm{i}}$ is the obtained value of the parameter, $\mathrm{V}_{\mathrm{o}}$ is the ideal value of the parameter, $\mathrm{V}_{\mathrm{s}}$ is the recommended Standard value of WHO for the ith parameter. $\mathrm{V}_{\mathrm{o}}$ shows the ideal value of the $\mathrm{i}^{\text {th }}$ parameter in clean water obtained from standard prescribed by the standard agencies, $\mathrm{V}_{\mathrm{o}}$ for $\mathrm{pH}$ and Dissolved Oxygen is taken as $7 \mathrm{pH}$ unit and $14.6 \mathrm{mg} / \mathrm{L}$ respectively. For the other parameter, the value of $\mathrm{V}_{\mathrm{o}}$ is taken as zero. ${ }^{32}$ The obtained values of the water quality index are further classified into five important categories and grades, as shown in Table-1.

Table-1: Water Quality Index (WQI), Status and different grades ${ }^{32-33}$

\begin{tabular}{l|l|l|l}
\hline S. No. & Classification of categories & WQI values & Grades \\
\hline 1. & Excellent water & $0-25$ & A \\
\hline 2. & Good water & $26-50$ & B \\
\hline 3. & Poor water & $51-75$ & C \\
\hline 4. & Very poor water & $76-100$ & D \\
\hline 5. & Water unsuitable for drinking purposes & above 100 & E \\
\hline
\end{tabular}

\section{pH Value}

\section{RESULTS AND DISCUSSION}

The $\mathrm{pH}$ value is an important parameter to decide water is acidic or alkaline in nature and play a significant role in its appropriateness for domestic, industrial and agricultural uses. The minimum and maximum allowable limit for $\mathrm{pH}$ in drinking water as given by CPCB and WHO is 6.5, 8.5 respectively. The $\mathrm{pH}$ values of the water samples collected from mines vary from 2.48 to 7.92 (Table-2, Fig.-1).The variations in $\mathrm{pH}$ range due to the chemical composition of the host rocks in the study area.

\section{Total Dissolved Solids (TDS)}

The presences of total dissolved solids (TDS) in water resources also play a significant role to decide its suitability of water for different uses. The concentration of TDS in the sample's water in our study area varies from 65 to $1650 \mathrm{mg} / \mathrm{L}$. (Table-2).Some mine water sample were fallen under higher solids content.

\section{Electrical Conductivity (EC)}

Electrical conductivity (EC) depends on the temperature and indirectly measure the salinity. ${ }^{34}$ The values of Electrical conductivity ( EC) (in $\mu \mathrm{S} / \mathrm{cm}$ ) in our study area were varying in the range from (130-2450). All values of Electrical conductivity (EC) were found under the allowable limit for irrigation and drinking water, except location 5 in the study area. When Electrical conductivity value exists at the range of 3000 $\mu \mathrm{S} / \mathrm{cm}$, the production of almost all the crops would be affected and as a result of fewer crops yield. ${ }^{35}$

\section{Hardness}

The concentration of hardness in the study area was ranging between (100-1100) $\mathrm{mg} / \mathrm{L}$. The acceptable limit of Hardness is (500-1500) $\mathrm{mg} / \mathrm{L}$ as per (WHO) recommendations.

\section{Calcium $\left(\mathbf{C a}^{2+)}\right.$}

The concentration of calcium ion in the study area was ranged between (24-668) $\mathrm{mg} / \mathrm{L}$. The accepted limit of calcium is $(75-200) \mathrm{mg} / \mathrm{L}$, as per (WHO) recommendations.

\section{Magnesium $\left(\mathrm{Mg}^{2+)}\right.$}

The occurrence of magnesium in water due to the presence of Augite, Biotite, Olivine and Talc minerals. The results showed that the magnesium in the mine water in the study area was varying from (20-79) $\mathrm{mg} / \mathrm{L}$. The permissible limit of magnesium is (30-150) $\mathrm{mg} / \mathrm{L}$. All value lies in the allowable range.

\section{Chloride $\left(\mathrm{Cl}^{-}\right)$}


RASĀYAN J. Chem.

Vol. 11 | No. 1 |46-52 | January - March | 2018

The Concentrations of chloride in natural water resources depend on geochemical conditions and vary from sites to sites. The range of chloride contents in the study area varied from (20-200) $\mathrm{mg} / \mathrm{L}$. All values are lies within the acceptable limit.

\section{Sulfate $\left(\mathrm{SO}_{4}{ }^{2-)}\right.$}

The Sulfate concentration in the water samples ranges from $(0-1122) \mathrm{mg} / \mathrm{L}$. The presence of a higher range of sulfate in mine water may be due to due to presence of Miocene sediments having gypsum and limestone. ${ }^{36}$ It causes noticeable taste and might contribute to the corrosion of distribution pipe network system. ${ }^{15}$

\section{Nitrate $\left(\mathrm{NO}_{3}\right)$}

The higher ranges of nitrate present in water resources may be noxious to a human being when its limit exceeds $45 \mathrm{mg} / \mathrm{L}$. The values of nitrates in the study area range from $(0-60) \mathrm{mg} / \mathrm{L}$.

\section{Turbidity}

Turbidity in the study area was varied between (0-6.3 NTU). The acceptable limit of turbidity is 5-25 NTU (WHO).All values nearly in the range of prescribed limits.

\section{Iron}

The concentration range of iron in the study area was ranging between (0.06-73.4) $\mathrm{mg} / \mathrm{L}$. The accepted limit of iron is $(0.1-0.3) \mathrm{mg} / \mathrm{L} \cdot{ }^{15,37}$ Its $50 \%$ values are a higher range of prescribed limits. These higher values are generally responsible for acidity in water resources.

The study results show $\mathrm{pH}$ at all the six sampling location ranged from 2.48 to 7.92 . The minimum $\mathrm{pH}$ value was observed in mine-5 (inactive mine) water sample. Total dissolved solids (TDS) ranged between $65-1640 \mathrm{mg} / \mathrm{L}$, EC ranged between 130 to $2450 \mu \mathrm{S} / \mathrm{cm}$, hardness, sulphate, iron content was found in the range of 100-1100, 0-1122, and 0.06-73.4 mg/ L respectively. The Physico-chemical result of sump water is shown in Table-2.

Table-2: Physico-chemical parameters of sump water and Water quality standards recommending agencies

\begin{tabular}{|c|c|c|c|c|c|c|c|c|}
\hline $\begin{array}{l}\text { Location } \rightarrow \\
\text { Parameter } \downarrow\end{array}$ & MINE-1 & MINE-2 & MINE-3 & MINE-4 & MINE-5 & MINE-6 & Standard & $\begin{array}{l}\text { Recommending } \\
\text { agencies }\end{array}$ \\
\hline $\mathrm{pH}$ & 6.51 & 7.92 & 7.87 & 6.15 & 2.48 & 7.82 & $6.5-8.5$ & BIS \\
\hline TDS & 745 & 117 & 262 & 397 & 1650 & 65 & 500 & WHO \\
\hline EC & 987 & 233 & 537 & 794 & 2450 & 130 & 400 & WHO \\
\hline Hardness & 100 & 260 & 170 & 110 & 1100 & 170 & 300 & BIS \\
\hline DO & 5.6 & 5.6 & 6.1 & 4.6 & 4.1 & 6.1 & 5 & BIS \\
\hline$\overline{\mathrm{BOD}}$ & 4.6 & 2.1 & 2.1 & 2.6 & 2.1 & 2.1 & 5 & ICMR \\
\hline Chlorides & 52 & 20 & 22 & 52 & 200 & 20 & 250 & ICMR \\
\hline Nitrates & 30 & 10 & 60 & 15 & NIL & NIL & 45 & BIS \\
\hline Sulphate & 1 & 100 & 50 & 300 & 1122 & NIL & 150 & BIS \\
\hline Turbidity & 4.6 & 6 & 6.2 & 6.3 & NIL & 1.84 & 5 & BIS \\
\hline Calcium & 57 & 32 & 72 & 136 & 668 & 24 & 75 & BIS \\
\hline Magnesium & 27 & 45 & 20 & 60 & 79 & 27.5 & 30 & BIS \\
\hline Iron & 2.843 & 0.16 & 0.17 & 6.25 & 73.4 & 0.06 & 0.3 & WHO \\
\hline
\end{tabular}

All parameters are given in $\mathrm{mg} / \mathrm{L}$, excluding $\mathrm{pH}$, Turbidity (NTU) and Electrical conductivity $(\mu \mathrm{S} / \mathrm{cm})$

From Table-3, water samples from five sampling location had WQI values greater than 100, which is not suitable for human utilization without suitable treatment. This higher value of WQI is found due to the presence of iron and sulphate in the water samples. In this study three locations had WQI values higher than the 100.WQI values range from 26.79 (Mine-6) to 19719.84 (Mine-5).In India higher value of WQI (700 ) also reported by ${ }^{14}$ for Tumkur mining area and 4294,Tarkwa Gold mining area in Ghana. ${ }^{38}$ 
RASĀYAN J. Chem.

Vol. 11 | No. 1 |46-52 | January - March | 2018

Table-3: Calculation of sub-indices and WQI for the sump water samples

\begin{tabular}{|c|c|c|c|c|c|c|}
\hline $\begin{array}{l}\text { Sample Location id } \rightarrow \\
\text { Parameter }\left(\mathrm{Q}_{\mathrm{I}} \mathrm{W}_{\mathrm{I})} \downarrow\right.\end{array}$ & MINE-1 & MINE-2 & MINE-3 & MINE-4 & MINE-5 & MINE-6 \\
\hline $\mathrm{pH} \mathrm{Q}_{\mathrm{I}} \mathrm{W}_{\mathrm{I}}$ & -.92896 & -1.7440 & 3.54570 & -1.62979 & -8.5708 & 1.55491 \\
\hline $\mathrm{TDS}_{\mathrm{I}} \mathrm{W}_{\mathrm{I}}$ & 0.072047 & 0.01130 & 0.02533 & 0.03880 & 0.15860 & 0.00628 \\
\hline EC QI $\mathrm{W}_{\mathrm{I}}$ & 0.14914 & 0.03520 & 0.08114 & 0.12108 & 0.37041 & 0.01964 \\
\hline Hardness $\mathrm{Q}_{\mathrm{I}} \mathrm{W}_{\mathrm{I}}$ & 0.026868 & 0.06980 & 0.04566 & 0.02980 & 0.29549 & 0.04566 \\
\hline DO Q $\mathrm{W}_{\mathrm{I}}$ & 4.53318 & 4.53300 & 5.89918 & 5.08430 & 5.2919 & 4.28126 \\
\hline BOD $Q_{I} W_{I}$ & 4.44856 & 2.03086 & 2.03086 & 2.54200 & 2.03196 & 2.03086 \\
\hline Chlorides $\mathrm{Q}_{\mathrm{I}} \mathrm{W}_{\mathrm{I}}$ & 0.020115 & 0.00773 & 0.00851 & 0.02033 & 0.07741 & 0.00773 \\
\hline Nitrates $\mathrm{Q}_{\mathrm{I}} \mathrm{W}_{\mathrm{I}}$ & 0.358177 & 0.11927 & 0.71633 & 0.18106 & 0.0000 & 0.0000 \\
\hline Sulphate $\mathrm{Q}_{\mathrm{I}} \mathrm{W}_{\mathrm{I}}$ & 0.00061 & 0.06040 & 0.03022 & 0.18330 & 0.67853 & 0.0000 \\
\hline Turbidity $\mathrm{Q}_{\mathrm{I}} \mathrm{W}_{\mathrm{I}}$ & 4.4485 & 5.80248 & 5.99589 & 5.86660 & 0.0000 & 1.77942 \\
\hline Calcium $\mathrm{Q}_{\mathrm{I}} \mathrm{W}_{\mathrm{I}}$ & 0.24499 & 0.13753 & 0.30946 & 0.58450 & 2.8730 & 0.10315 \\
\hline Magnesium $\mathrm{Q}_{\mathrm{I}} \mathrm{W}_{\mathrm{I}}$ & 0.72531 & 1.20885 & 0.53720 & 1.61180 & 2.1233 & 0.73870 \\
\hline Iron $\mathrm{Q}_{\mathrm{I}} \mathrm{W}_{\mathrm{I}}$ & 763.71 & 42.7217 & 45.6622 & 1697.22 & 19728.29 & 16.1180 \\
\hline$\Sigma \mathrm{Q}_{\mathrm{I}} \mathrm{W}_{\mathrm{I}}$ & 776.73 & 54.983 & 64.887 & 1711.84 & 19733.60 & 26.687 \\
\hline WQI & 779.85 & 55.204 & 65.148 & 1719.79 & 19719.84 & 26.79 \\
\hline
\end{tabular}

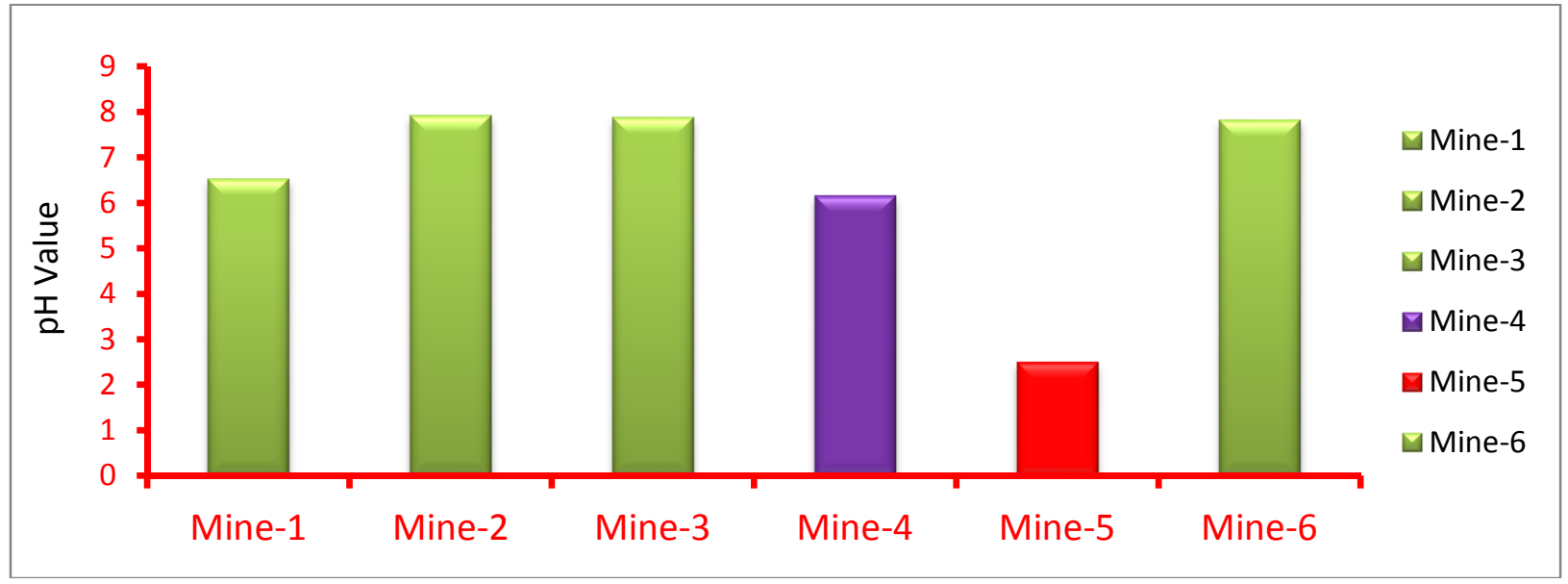

Fig.-1: Graphical Representation of $\mathrm{pH}$ value of a different mine

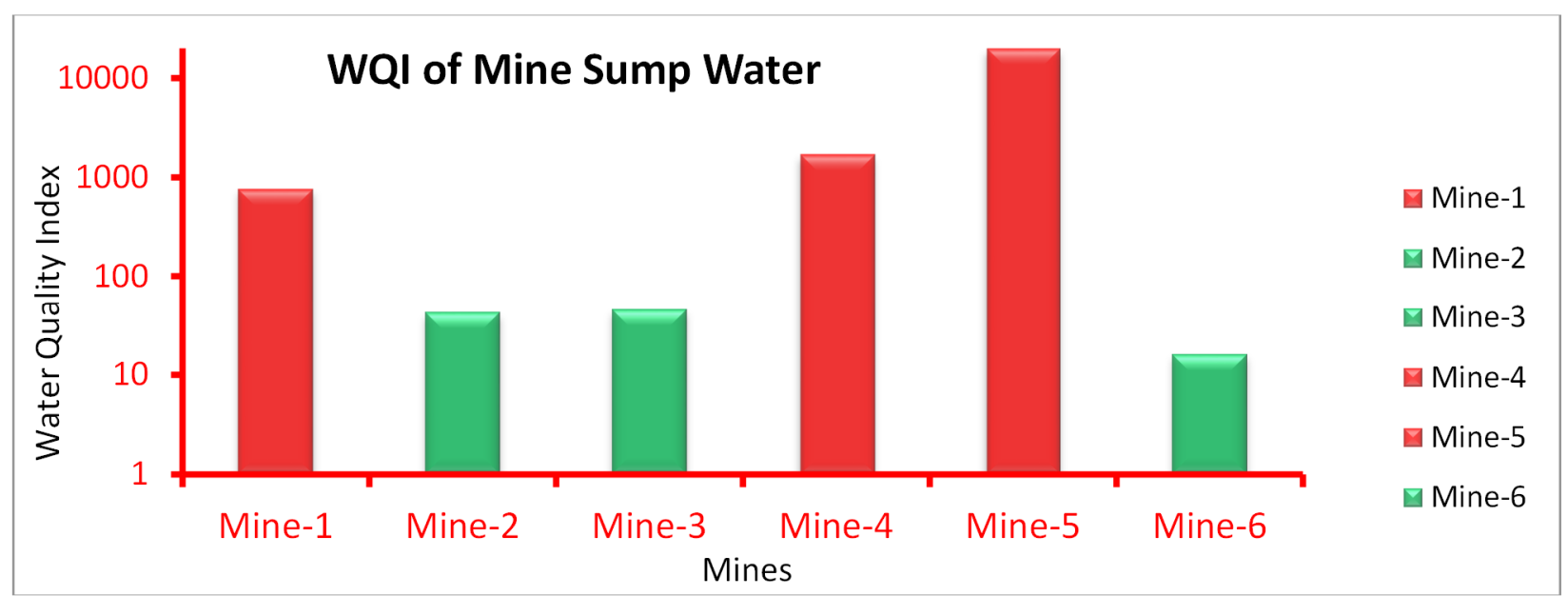

Fig.-2: Graphical Representation of WQI of different coal mines 


\section{CONCLUSION}

The study data show the WQI of mine water samples varies from 26.79 to 19719.84 .The higher value of WQI was found due to the presence of iron, nitrate, total dissolved solids and sulphate, in main sump water sample. The highest pollution level was found in the mine-1, mine-4 and mine-5 (closed), opencast coal mines. The other three sump water (mine-2, mine-3, and mine-6) can be used after small treatment. Present time all mines in India, working on the concept of zero waste discharge and reuse mine water for different purposes inside the mines. Although in the present condition all water samples collected from various mines not suitable for any domestic and industrial purposes, before discharging in any water resources, needs proper effective treatment.

\section{ACKNOWLEDGEMENT}

The authors are especially grateful to the Indian Institute of Technology, Banaras Hindu University, Varanasi for providing technical support and co-operation during the whole study period.

\section{REFERENCES}

1. R.C.Trivedi, R.M.Bhardwaj, S. Agarwal, In: Proc.of Taal The 12th World lake Conf. (2007).

2. Imran Khan, Javed, Akram., Khurshid, Shadab, Environ. Earth Sci., 68, 1849(2013).

3. B. B., Dhar, S., Ratan, and A., Jamal, J. of Mines Metals and Fuels, 34 (12), 596(1986).

4. H.L. Yadav and A. Jamal, Int. Adv. Res. J. in Sci. Engg. And Tech., 3(11)116(2016).

5. H.L. Yadav and A. Jamal, Int. J. of Adv. Res., 3(10)1009(2015).

6. H.L. Yadav and A. Jamal, Int. J. of New Tech. Sci. and Engg.,2(3)77 (2015).

7. H.L. Yadav and A. Jamal, Int. J. of Adv. Res., 4 (6)310(2016).

8. H.L. Yadav, and A. Jamal, Rasayan J. Chem., 10(3), 891(2017).

9. H.L. Yadav and A. Jamal, Rasayan J. Chem., 10(3), 1062(2017).

10. P. K., Singh, A.K., Tiwari, and M.K. Mahato, Int. J. of Chem. Tech. Res.,5(5),2351(2013).

11. R. Reza, G., Singh, World Appl. Sci J., 9(12), 1392(2010).

12. T.V.Ramachandra, M. Solanki, Bangalore Eco. Assessment of lentic water bodies of Bangalore, (2007).

13. WHO Guidelines for Drinking Water Quality, 2nd Ed., 1,188(1993).

14. C. R. Ramakrishnaiah, C. Sadashivaiah, G. Ranganna, E. J. of Chemistry,6(2),523 (2009).

15. WHO, Guidelines for Drinking Water Quality, Geneva, Switzerland, (2011).

16. Shweta Tyagi, Bhavtosh, Sharma, Prashant,Singh, and Rajendra Dobhal, J. of Water Res., 1(3)34(2013).

17. Kaswanto, Regan., Kaswanto, Leonardus., A.H.Susilo., Nakagoshi, Nobukazu.,. Int. J. of Env. Prot., 2 (12), 17(2012).

18. APHA (American Public Health Association) Standard Methods,(20th Edn.) Washington DC: APHA, AWWA, WEF (2005).

19. APHA (American Public Health Association, (20th Edn.) Washington DC: APHA, AWWA, WEF, (1998).

20. J.R.Dojlido, G.A. Best, Chemistry of Water and Water Pollution. London: Ellis Horwood,(1993).

21. C.E. Steinhart, L.J. Schierow, G. Chesters, Uni.of Wisconsin, Madison, Wisconsin, 53706, USA, (1981).

22. S.B. Shankar, L.Sanjeev, Environmental Engineering Science, 25(6), 911(2008).

23. V. Sladecek, Arch .hydrobiol. beih. ergebnisse der limnologie,71,218(1973).

24. S. F.Babaei, J. of Water Sci. and Tech., 64, 2483(2011).

25. R. Rizwan, and S. Gurdeep, World App. Sci. J., 9(12), 1392(2010).

26. A. A., Mahmood, A. M., Essa, M. H., Mohammed, and I. Y, Shbbar, J. of Babylon University / Pure and Applied Sci., 7(21),2531 (2013).

27. H. Q. Khan, Env. Earth Sci., 1255(2011).

28. R.M. Ketata, M.Gueddari, R. Bouhlila, Iran. J. Energy Environ., 2(2),133(2011). 
RASĀYAN J. Chem.

Vol. 11 | No. 1 |46-52 | January - March | 2018

29. S.Naik, K.M.Purohit, J. Environ Ecoplann., 5(2),397(2001).

30. R.M., Brown, N.J.,MeCeiland, R.A.Deinimger, and R.G. A. Tozer, Water Sewage Works, 117,339(1970).

31. J. Srinivas, A.V. Purushotham, and Murali K.V.S.G., Krishna, Int. Res. J. Env. Sci., 2(5), 37(2013).

32. G. Singh, and R.K. Kamal, Current World Environment, 9 (3), 994(2014).

33. G.K. Khadse, P.M. Patni, and P.K. Labhasetwar, Sust. Water Res. Management, 2(2), 121(2016).

34. J. D.Hem, Study and Interpretation of Chemical Characteristics of Natural Water: USGS Professional Paper Book, 2254, Sci. Pub., Jodhpur, (1991).

35. K. Jothivenkatachalam, A. Nithya and S. Chandra Mohan, Rasayan J. Chem., 3(4), 649 (2010).

36. Al-Suhail,Qusay and H, Al-Mansoury., Pure Sci. J., 30,317(2003).

37. A. K. Haritash, Shalini Gaur, Sakshi Garg., India Appl. Water Sci., 6,383(2016).

38. Armah, A. Frederick Luginaah, Isaac, Son, A. Benjamin, The J. of Tran Dis. Env. Studies, 11(2) 1(2012).

[RJC-1961/2017] 